\title{
W KIERUNKU ANIMAL STUDIES. STUDIA NAD STOSUNKIEM DO ZWIERZĄT W XX W.
}

Zamieszczone poniżej studia stanowia jedne z pierwszych prób zmierzenia się z tematyka, która jest czymś nowym na gruncie polskiej historiografii dziejów najnowszych. Chodzi o studia nad zwierzętami, a ściślej nad stosunkiem ludzi do zwierząt w kontekście historycznym.

Brak takich badań to zaniedbanie, które warto nadrobić. Tym bardziej że studia nad zwierzętami rozpoczęły się na Zachodzie w sposób bardziej systematyczny w latach siedemdziesiątych XX w. Zaczęto wówczas wręcz mówić o tzw. zwrocie zwierzęcym (animals turn) w humanistyce. Odbywało się to w szerszym kontekście polityczno-kulturowym, obejmującym ekologię, ruchy na rzecz praw obywatelskich, w tym praw kobiet. Ruch wyzwolenia zwierząt był fragmentem tych procesów. Brak poszanowania dla zwierząt zaczęto traktować jako element antropocentryzmu w wymiarze moralnie niepokojacym, nazwanym szowinizmem gatunkowym ${ }^{1}$. Fundamenty dla nowego sposobu traktowania zwierzat, również w badaniach naukowych, dały prace psychologa Richarda D. Rydera $^{2}$ i filozofa Petera Singera ${ }^{3}$. Ruch wyzwolenia zwierząt zaczą się rozwijać jako ważny nurt aktywności społecznej.

Zainteresowanie zwierzętami zaczęła przejawiać także zachodnia historiografia. Stały się przedmiotem studiów z zakresu historii kulturowych, historii medycyny, technologii, nauki, marginalizacji, historii

${ }^{1}$ M. Bakke, Studia nad zwierzętami: od aktywizmu do akademii $i$ z powrotem?, „Teksty Drugie” 2011, nr 3, s. 194-195; próbę syntezy osiagnięć badań nad historią zwierząt zob. E. Domańska, Historia zwierzat, „Konteksty. Polska Sztuka Ludowa” 2009, nr 4, s. 322-331.

2 R.D. Ryder, Animal Revolution. Changing Attitudes toward Speciesism, Oxford 2000 .

${ }^{3}$ Wyd. pol.: P. Singer, Wyzwolenie zwierzat, tłum. A. Alichniewicz, A. Szczęsna, Warszawa 2004. 
środowiskowej, intelektualnej itp. Poświęca się im znaczące miejsce w próbach kontekstualizacji historii powszechnej, globalnej czy ewolucyjnej ${ }^{4}$.

Część badaczy umieszcza historię zwierząt w perspektywie posthumanistyki. Oznacza to m.in., że zwierzęta, jak to ujęła Ewa Domańska, „nie sa badane jako symbole czy jako "narzędzia» wykorzystywane przez człowieka, ale jako istnienia, z którymi ludzie dzielą świat i go współtworza”. Podejście takie „stymuluje zainteresowanie zwierzęcością człowieka i przypomina, że z punktu widzenia biologii człowiek jest zwierzęciem, zatem ważne jest przebadanie idei i praktyk, które doprowadziły i legitymizowały separację człowieka od zwierzęcia i ideę ludzkiej wyjątkowości”.

W polskiej historiografii i - szerzej - humanistyce „wątki zwierzęce” są stosunkowo rzadkie. Badacze zajmuja się nimi niejako na marginesie swoich głównych zainteresowań, traktując często jako rodzaj ciekawostki. Stosunkowo największy dorobek mają literaturoznawcy i historycy sztuki. Najczesściej podejmowali oni studia nad motywami zwierzęcymi w twórczości poszczególnych pisarzy czy artystów, ale nie składają się one na większą, spójną całość. Przedmiotem analiz był również język dyskursu na temat zwierząt. Realizowane były też finansowane przez państwo projekty naukowe stawiające zwierzęta w centrum zainteresowania ${ }^{6}$.

Prace badaczy, tak polskich, jak i zagranicznych, zajmujących się historia zwierząt w Polsce (lub na ziemiach polskich), w tym ich relacjami ze światem ludzi, nie sa liczne. Ciekawe studia na ten temat, obejmujące okres międzywojnia, opublikowała Eva Plach ${ }^{7}$. O organizacjach

${ }^{4}$ D. Vandersommers, The „Animal Turn” in History, https://www.historians.org/ publications-and-directories/perspectives-search?Keywords=november-2016\%2Ftheanimal-turn-in-history (27 II 2019).

${ }^{5}$ E. Domańska, Historia $w$ kontekście posthumanistyki, „Historyka. Studia Metodologiczne” 45, 2015, s. 19-20; zob. też: K. Nowak, Animal studies - wyzwanie dla historiografii?, https://histmag.org/Animal-studies-wyzwanie-dla-historiografii-3208 (27 II 2019).

${ }^{6}$ Zob. m.in. Zwierzęta $i$ ich ludzie. Zmierzch antropocentrycznego paradygmatu, red. A. Barcz, D. Łagodzka, Warszawa 2015; Człowiek $w$ relacji do zwierzat, roślin $i$ maszyn $w$ kulturze, t. 1: Aspekt posthumanistyczny $i$ transhumanistyczny, t. 2: Od humanizmu do posthumanizmu, red. J. Tymieniecka-Suchanek, Katowice 2014.

7 E. Plach, Ritual Slaughter and Animal Welfare in Interwar Poland, „East European Jewish Affairs" 45, 2015, nr 1, s. 1-25; taż, Mad Dogs and Animal Protectionists. Rabies in Interwar Poland, „Canadian Slavonic Papers” 55, 2013, nr 3-4, s. 391-416; taż, Dogs and Dog Breeding in Interwar Poland, „Canadian Slavonic Papers” 60, 2018, nr 3-4, s. 471-496. 
ochrony zwierzat w II Rzeczypospolitej pisała Edyta Wolter ${ }^{8}$. Historycy polscy nie zajmowali się również szerzej historią zwierząt z perspektywy historii powszechnej. Stosunkowo większe zainteresowanie budziły dawne procesy zwierzat ${ }^{9}$. Ciekawe badania na temat funkcji deratyzacji w Polsce Ludowej podjęła Gabriela Jarzębowska ${ }^{10}$.

Prezentowane studia mają ambicje wzbogacenia niewielkiej wiedzy na ten temat i wskazania, że zajmowanie się historią zwierząt, w tym ich relacjami z ludźmi, to pasjonujący obszar badawczy, który warto drążyć.

${ }^{8}$ E. Wolter, Dziatalność Polskiej Ligi Przyjaciót Zwierzat/Polskiej Ligi Ochrony Zwierzat w II Rzeczypospolitej, „Analecta” 2017, nr 2.

${ }^{9}$ Zob. m.in. tekst literaturoznawcy Andrzeja Dąbrówki, Dawne procesy zwierzat jako dramaty rytualne, „Teksty Drugie” 2002, nr 5, s. 23-35; zob. też G. Fesnak, Zwierzęta $w$ średniowiecznym i nowożytnym sqdzie, „Mówią Wieki” 2016, nr 10, s. 36-39.

${ }^{10}$ G. Jarzębowska, Retoryka deratyzacji w PRL. Od czystki etnicznej i politycznej do czystki gatunkowej, „Teksty Drugie” 2018, nr 2, s. 120-137. 